\title{
Can Projection Information Shed Light On Post Bankruptcy Performance?
}

\section{Ben Branch ${ }^{1}$ and Min $\mathbf{X u}^{2 *}$}

${ }^{1}$ Isenberg School of Management, University of Massachusetts - Amherst, Amherst, USA

${ }^{2}$ College of Business Administration, University of Detroit Mercy, USA

\begin{abstract}
As we find the different ways that bankrupt companies file their projection information during Chapter 11 process, we incorporate the regression analysis to investigate what firm characteristics lead to the difference, and whether two types of projection, either high quality or low quality, indicates the efficiency of the restructuring plan so that it will be reflected in their postbankruptcy performances. Our results identify that firms in better financial position tend to offer complete projection information, but the quality of projection information is not significantly contributing to their post-bankruptcy performances.
\end{abstract}

Keywords: Bankruptcy; Chapter 11; Projection; Z-score

\section{Introduction}

In the United States, formal bankruptcy practices are conducted according to the provisions of the Bankruptcy Reform Act of 1978 and more recently the Bankruptcy Reform Act of 2005. Corporations may file liquidation under Chapter 7 or reorganization under Chapter 11 through one of the 94 regional bankruptcy courts. In Chapter 7, all of its business operations will be ceased and all of the assets will be liquidated. The court will govern the liquidation process. A Chapter 7 trustee will be appointed by the U. S. Trustee, and the trustee will organize a sale of all the firm's assets. The primary role of a Chapter 7 trustee is to liquidate the debtor's assets in a manner that maximizes the return to the debtor's unsecured creditors. Proceeds from the asset sales will be distributed to the creditors according to absolute priority rule. That is, the junior creditors will not receive any proceeds until all the senior claims are paid in full. A Chapter 7 filing contemplates the end of the filer as a separate company.

With a Chapter 11 filing, in contrast, corporations attempt to reorganize their business and restructure their debts so as to emerge as a viable entity no longer in bankruptcy. Therefore, Chapter 11 bankruptcy is often referred to "reorganization" bankruptcy. The key goal is to provide companies with an opportunity to undertake some form of reorganization to have a fresh start, and to enable the financially troubled firm to continue to operate the business under the supervision of the court and maintain its remaining goodwill rather than to liquidate its assets in a sale. In Chapter 11, unless a separate trustee is appointed for cause, the debtor, as debtor in possession, acts as trustee of the business.

Only the debtor may file a plan of reorganization during the first 120 days after the Chapter 11 petition filing. The plan contains the proposed restructuring plans and distributions to those possessing financial claims on the debtor firms. It specifies what each class of claimants will receive in exchange for their pre-Chapter 11 claims. The plan not only needs to be confirmed by the court, but equally importantly, it needs to be approved by at least a majority in number and two-thirds of the dollar values held by each class of creditors. A successful reorganization plan must demonstrate to the court that the firm is unlikely to re-file for bankruptcy in the near future. In some cases, more than one plan may be submitted to creditors for approval. The debtor must also file a written disclosure statement and obtain court approval before a vote on the plan of reorganization can be taken. The disclosure statement must provide adequate information to claim holders in order to allow them to make an informed judgment about the plan. Usually a disclosure statement will include financial statements for the past three to five years before Chapter 11 filing and it may also include a projection of financial information for three to five years after emergence from Chapter 11.

One question that comes to our mind is - how accurate and reliable is the projected information released in the disclosure statement? The feasibility and effectiveness of a restructuring plan play an important role in the plan's success, and disclosure statement is supposed to provide adequate information for the bankruptcy case's claimants to vote the plan up or down. Therefore, for those projected numbers, can they offer any guidance and insights into the future of those bankrupt companies? Are they similar to the analysts' estimates given on a stock? When we look closer at those projections, the ways they file those numbers differ from company to company. Some companies offer very detail projection information with most of the accounting items listed in the forecasted balance sheet, income statement, and cash flow statement for the next three to five years. On the other hand, some firms file a very brief projection, releasing limited information, and some may choose not to provide the numbers at all. Why those troubled companies differ in the information releasing behavior? Is it because some companies are more resource constraint compared to others? For example, some bankrupt firms may choose to hire a group of turnaround professionals to work on the restructuring plan and provide adequate estimation for future performance, however, the cost of hiring those experts could be huge to those distressed firms who are already short on cash and facing to limited financing sources. Further, is it because a firm has a specific and feasible restructuring plan, then it is able to offer detail projection information? In other words, by offering complete projection information, does it indicate a well-thought plan behind those numbers? If yes, then it should be able to help the companies emerge from bankruptcy and be reflected in the post-bankruptcy performances as the companies continue to

${ }^{*}$ Corresponding author: Min Xu, Assistant Professor of Finance, College of Business Administration, University of Detroit Mercy, USA, Tel: 313-993-1225; Fax: 313-993-1673; E-mail: xumi@udmercy.edu

Received September 19, 2013; Accepted December 18, 2013; Published January 02, 2014

Citation: Branch B, Xu M (2014) Can Projection Information Shed Light On Post Bankruptcy Performance? Bus Eco J 5: 084. doi: 10.4172/2151-6219.1000084

Copyright: $\odot 2014$ Branch B, et al. This is an open-access article distributed under the terms of the Creative Commons Attribution License, which permits unrestricted use, distribution, and reproduction in any medium, provided the original author and source are credited. 
operate as an independent company. Therefore, these become our main research questions in this paper. We are testing the following two hypotheses: 1) A company in stronger financial performances will be more likely to file complete projection information; 2) Completeness of projection information indicates an efficient restructuring plan so that the companies will enjoy better post-bankruptcy performances.

To test those hypotheses, our paper is focused on two groups of firms that successfully emerged from Chapter 11 as public companies in which we can track their post-bankruptcy measures. One group offer detail and complete projection information. We call them the high quality group. While the other one only release limited or no projection information. We call them low quality group. Overall, we find that companies offering high quality projection information are the ones in stronger financial performances in both pre- and post-bankruptcy period. Their comparatively better post-bankruptcy positions might be simply stemmed from the good status in pre-bankruptcy period. To eliminate this possible situation, instead of tracking their absolute performances, we focus on the change from post- to pre-bankruptcylevel in order to find out which group tends to enjoy greater improvements. The descriptive statistics show the signs that high quality group do a better job in terms of decreasing debt burden and increasing equity and profit. Not surprisingly, the actual post-bankruptcy performances are not as optimistic as they projected in the disclosure statements and the gap tends to widen over the years. In our regression analysis, we do find supporting evidence to our first hypothesis that companies in larger sizes, higher liquidity and profitability, and less distress risk are more likely to file high quality projection information. However, offering a high quality projection is not significantly related to the improvements from pre- to post-bankruptcy level. We do not find sufficient results to support our second hypothesis. Among all the results, the liquidity and profitability play a key role in explaining the improvements.

Our paper contributes to the current literature in several ways. First, we are one of the pioneer works that address the different ways companies filing for the same piece of information in disclosure statement, and further identify the firm characteristics explaining the difference in this reporting behavior. Second, we extend the investigation period into the during-Chapter 11 bankruptcy process. Whether a company can be saved and continue on its own will depend on whether it has a feasible and effective road map. Therefore, the information generated during the Chapter 11 bankruptcy process may provide some valuable insights and should not be ignored. Third, by bridging projected information with actual performances later, we not only confirm the over-optimism in the projection information, but also reveal a decay effect in which the gap widens over the years. Further, the linkage also reveals whether projection information can provide any forecast power into the troubled companies' future financial condition. The quality is important because it can reflect the motivation of the troubled companies filing those projected numbers, whether they have a specific plan in mind and are dedicated to it, or those numbers are just a part of procedures in Chapter 11 bankruptcy and they just fulfill their to-do list to show to bankruptcy judges.

The remainder of the paper is organized as follows. Section 2 is the literature review. Section 3 discusses the data process and various performance measures. Section 4 reports results and discussions of our analysis. The conclusion is in Section 5.

\section{Literature Review}

Chapter 11 outcomes vary. Some companies liquidate, others may be acquired or merged with another company, and some may successfully emerged from Chapter 11, either as a private or public companies. Hotchkiss [1] examined a sample of 806 public companies that filed for Chapter 11 between 1979 and 1988, finding that 197 (24\%) emerged as public companies. Eberhart et al. [2] investigated 546 chapter 11 filing from 1980 to 1993, finding that 131 (24\%) emerged as public companies. Bris et al. [3] tested 225 Chapter 11 cases and 61 Chapter 7 cases from the bankruptcy courts of Arizona and the Southern District of NY from 1995 to 2001 . They found that 52\% continued as independent companies when they emerge from Chapter 11. Hotchkiss and Mooradian [4] examined 1200 public companies who filed for $\mathrm{Ch}$ 11 between Oct 1979 and Dec 1992. They found 339 (28\%) reorganized as independent public companies, 111 (9\%) were acquired, of which 55 were acquired by public companies. Morrision [5] assembled a sample of 95 relatively small Ch 11 bankruptcy filings in the Northern District of Illinois in 1998. He found 9 (9\%) were sold as going concerns, 27 (28\%) exit as reorganized entities, 29 (30\%) shut down in bankruptcy, and $30(33 \%)$ liquidate.

Some studies have examined factors influencing whether a firm can successfully emerge from Chapter 11 . Hotchkiss [6] showed that firm size, measured by pre-petition assets, is the most important characteristic determining whether a firm will successfully reorganized. Many of the emerging firms downsize during Chapter 11. Denis and Rodgers [7] find that larger firms are more likely to survive the Chapter 11 process and emerge as independent companies because they have greater survival resources. Duration is also an interesting aspect in Chapter 11. Li [8] shows that the longer a firm stays in Chapter 11, the less likely is it to exit as a reorganized firm. Denis and Rodgers [7] found that firms with smaller size, better operating performance, and higher operating margins spend less time in Chapter 11. Firms are more likely to emerge as going concerns and to achieve positive post-reorganization profitability if they downsize significantly while in Chapter 11. Bris et al. [3] find that the time in bankruptcy is a useful proxy for indirect bankruptcy costs. They also found that firms with more secured creditors tend to spend more time in bankruptcy. Moreover, they find the relationship between asset size and bankruptcy duration is weak or nonexistent. Moreover, the judge effect in Chapter 11 is also well documented. The most popular regional bankruptcy courts are District of Delaware and District of Southern New York. Hotchkiss [1] applies a dummy variable for the cases filed in the southern district of New York. The results show that cases filed in this district have a somewhat higher probability of entering a second bankruptcy or distress restructuring.

Regarding the projection information, Hotchkiss [1] shows that the median forecast errors in each year studied are negative and differ significantly from zero. The forecast presented at the time of reorganization may reflect the reporting incentives of the persons preparing those forecasts. In addition, she also found that particularly poor performance before bankruptcy is associated with particularly poor performance after bankruptcy. Lehavy [9] reports two conflicting incentives for firms adopting fresh start reporting. One is to overstate the projected equity value in order to promote the acceptance of the reorganization plan and expedite emergence from bankruptcy. The other one is to underestimate equity value in order to enhance reported performance post-bankruptcy. Gilson, Hotchkiss and Ruback [10] found that estimated values are generally unbiased, but that the dispersion of valuation errors is very wide. Betker et al. [11] report that the post-bankruptcy performance forecasts contained in disclosure statements tend to be systematically optimistic. Furthermore, they find a negative relation between the forecast error and the size of the firms as well as with the firm's capital intensity. 


\section{Data and Methodology}

\section{Data}

We obtain our initial sample of 1,117 firms that filed for bankruptcy between January 1978 and December 2006 from Professor Edward Altman at New York University. It contains bankruptcy filing of firms with liabilities at default of $\$ 100$ million or greater. We extend that database to 2010 by adding additional 239 cases with greater than $\$ 100$ million in liabilities from bankruptcydata.com. Therefore, our starting total is 1356 bankruptcy filings from 1978-2010. We restrict our sample period to $1986-2010$ as the New Generation Research database begins with 1986, thereby resulting in 1288 filings for $1986-2010$ period.

Next, we determine the bankruptcy outcome, filing date, confirmation date, and emergence date (if any) from Lexis-Nexis, New Generation Research, and form 10-K filings with the SEC. Table 1 reports the six bankruptcy outcomes of our sample: acquired/ purchased/merged, reorganized, converted to Chapter 7, liquidated, dismissed and undetermined.

Acquired/purchased/merged takes $12.7 \%$ of the entire sample, reorganized $40.8 \%$, convert to Chapter $76.4 \%$, liquidated $18.8 \%$, dismissed $2.7 \%$ and undetermined, in which the result was unknown or the firm remained in Chapter 11 , accounts $18.6 \%$. Of those successfully reorganized through Chapter $11,24 \%$ emerged as public companies and $13 \%$ became private ones (Table 1 ).

Whether the restructuring plan they proposed will help the company to continue in an improved condition beyond the emergence from bankruptcy? We want to keep track of their after bankruptcy financial condition, therefore, we target the ones that successfully emerged from Chapter 11 as public companies, the $24 \%$ in our entire sample. For those emerged public companies, we collected annual accounting variables from Compustat and SEC for three years before and after Chapter 11.

Last step in the data collection process, but not the least, is to locate their plan of reorganization and disclosure statement from PACER (Public Access to Court Electronic Records). From the documents they filed to the bankruptcy court, we manually screen them and extract the projection information. For those $24 \%$ of the emerged public companies, in which we have 309 firms, we are able to identify 211 firms with available plan of reorganization and disclosure statement. However, we find that not every company submitted the information in

\begin{tabular}{|c|c|c|}
\hline Outcome & Number of Firms & Percentage \\
\hline Acquired/Purchased/Merged & 163 & $12.7 \%$ \\
\hline Reorganized & & \\
\hline - public firms & 309 & $24.0 \%$ \\
\hline - private firms & 168 & $13.0 \%$ \\
\hline - others & 49 & $3.8 \%$ \\
\hline Convert to Chapter 7 & 82 & $6.4 \%$ \\
\hline Liquidated & 242 & $18.8 \%$ \\
\hline Dismissed & 35 & $2.7 \%$ \\
\hline Undetermined & 240 & $18.6 \%$ \\
\hline Total & 1288 & $100.0 \%$ \\
\hline
\end{tabular}

Bankruptcy outcomes are classified into six groups: acquired/purchased/merged reorganized, convert to Chapter 7 , liquidated, dismissed, and undetermined. Acquired/purchased/merged firms sell substantially all of its assets to a single buyer while in bankruptcy. Undetermined outcomes are those for which the result is unknown or the firm remained in Chapter 11as of year end 2010. We focus on the firms that successfully emerged from Chapter 11 as public companies.

Table 1: Bankruptcy Filing Outcomes. the same manner. Some companies filed a detail projected balance sheet and income statement for the anticipated 3-5 years after emergence from bankruptcy, while some companies either did not file the information or the information was too brief to conduct any numerical analysis. Hence, of those 211, 102 firms offered complete projection information and the remaining 109 were either with no information or too brief information. Therefore, we put them into high quality group (102 firms with complete projection information) and low quality group (109 firms with incomplete or no projection information).

\section{Methodology}

We use t-test to compare various measures between high quality group and low quality group, and run three regressions to test our two hypotheses. Please see the detail regression setup in the next section. We construct a group of explanatory variables to evaluate the financial condition of our sample firms. The measures include:

- Total assets (in millions)

- Total liabilities (in millions)

- Total equities (in millions)

- Net income (in millions)]

- Book-to-market ratio=Book value of firm / market value of firm

- $\mathrm{CA} / \mathrm{TA}=$ current assets / total assets, a liquidity measure

- $\mathrm{ROE}=$ net income / total equities, a profitability measure

- $\mathrm{ROA}=$ net income / total assets, a profitability measure

- Rev/TA=total revenue / total assets, a productivity measure

- Equity / TL=total equities / total liabilities, a measure of the value of firms' equity from the market perspective

- Z-score, an overall bankruptcy risk measure for which below zero indicates a distressed condition.

The Z-score is calculated based on the revised version in Altman [12], which is

$$
Z^{\prime \prime}=3.25+6.56 \mathrm{X}_{1}+3.26 \mathrm{X}_{2}+6.72 \mathrm{X}_{3}+1.05 \mathrm{X}_{4}
$$

where,

o $\mathrm{X}_{1}=$ (current assets - current liabilities $) /$ total assets,

$\mathrm{o} \mathrm{X}_{2}=$ retained earnings / total assets

$\mathrm{o} \mathrm{X}_{3}=\mathrm{EBIT}$ (earnings before interest and taxes) / total assets

o $\mathrm{X}_{4}=$ book value of equity / total liabilities

In addition, to control for industry characteristics, we also assign our sample into five different categories based on their SIC code according to Fama-French industry classification. The five industries are: Cnsmr (Consumer Durables, NonDurables, Wholesale, Retail, and Some Services), Manuf (Manufacturing, Energy, and Utilities), HiTec (Business Equipment, Telephone and Television Transmission), Hlth (Healthcare, Medical Equipment, and Drugs), and Other (Mines, Construction, Transportation, Hotels, Business Service, Entertainment, Finance). Further, we exclude all the financial and utility firms as the financial decisions of utility firms are affected by regulation and the financial ratios of financial firms are not comparable to those of other industrial firms.

\section{Results and Discussion}

Table 2 lists the descriptive statistics for both high quality group and low quality group in one year before bankruptcy (pre-1) and one year after emergence from bankruptcy (post-1). In pre-1 we can see 
that both groups are in severe financial trouble and high distress risk, as shown from the negative $Z$-scores of -1.67 and -3.70 respectively. Both groups suffer from high debt burden, low equity, negative net income, and low liquidity, profitability, and productivity. The comparison between the two groups shows that high quality group are larger in size, have more debt, higher profitability and less distress risk compared to low quality group. Once they emerge out of bankruptcy, in post-1, the situation almost remains the same. High quality group still enjoy higher Z-score and larger in size, liability, and net income. Hence, it could be a simple carry-over effect, that is, high quality group contain stronger companies before bankruptcy, and even after the Chapter 11 restructuring process, they emerge and are still stronger compared to low quality group. To control for their pre-bankruptcy status, instead of focusing on the absolute performance measures, we track the change throughout Chapter 11, post-bankruptcy minus pre-bankruptcy level, to see whether complete projection information indicates a more detail and feasible restructuring plan so that distressed firms can enjoy a more significant improvement. When comparing the change from post- to pre-bankruptcy, both groups enjoy improvements as they decrease their size and liability, and improve in almost every other measures including equity, net income, liquidity, profitability, productivity, and overall bankruptcy risk. When comparing across the two groups, in $\Delta$ High $-\Delta$ Low, we do find some evidence that high quality group cut more liabilities, and increase more in equity and net income (Table 2).

Next, we check out the quality of projection information in Table 3. We take the actual performance measures minus their projected level up to three years after emergence from bankruptcy to see how large the deviation is. The larger the deviation, the better the improvement throughout the restructuring in bankruptcy. For all the measures, almost all the deviations are negative and significant from zero, indicating that the actual performance after bankruptcy are actually worse than their projected level. In other words, the projection information tends to be too optimistic. This is consistent with the existing literature. In particular, the situation tends to deteriorate over the years. For example, the deviation in the liquidity measure, CA/TA, is - 0.04 in year one after bankruptcy, and later it expands to -0.05 in two years after bankruptcy and -0.08 in three years after bankruptcy (Table 3 ).

Now, we are eager to run the regression test to investigate: (1) what type of companies tends to file high quality projection information; (2) whether filing a high quality projection indicates a more detail and feasible restructuring plan so that the distressed firms will enjoy a more significant improvement. To control for the pre-bankruptcy status, we take the accounting variables in pre-1 into our regression. Table 4 lists the correlations between those variables, and we do not find a high correlation which will lead to a multicollinearity problem in a regression (Table 4).

To find out the answer to question 1, we run a logit regression. The dependent variable is a dummy variable for projection, 1 for high quality and 0 for low quality. The independent variables include all firm characteristics in pre-bankruptcy, a dummy for bankruptcy court, 1 for Delaware and New York Southern and 0 otherwise, and control dummies for different industry sectors. Bankruptcy courts of Delaware and New York Southern are famous for their debtor friendly attitude.

\begin{tabular}{|c|c|c|c|c|c|c|c|c|c|}
\hline & \multicolumn{3}{|c|}{ Pre-1 } & \multicolumn{3}{|c|}{ Post-1 } & \multicolumn{3}{|c|}{ Post1- Pre1 } \\
\hline & High & Low & High - Low & High & Low & High - Low & $\Delta$ High & $\Delta$ Low & $\Delta$ High - $\Delta$ Low \\
\hline Total Assets & 1829 & 732 & $1097^{* * *}$ & 1496 & 514 & $982^{* * *}$ & $-319^{* * *}$ & $-211^{* * *}$ & -108 \\
\hline Total Liabilities & 1693 & 800 & $893^{* * *}$ & 1046 & 403 & $643^{* * *}$ & $-641^{* * *}$ & $-390^{* * *}$ & $-252^{* *}$ \\
\hline Total Equities & 66 & -5 & 70 & 366 & 114 & $252^{* \star *}$ & $299^{* \star *}$ & $114^{* * *}$ & $185^{\star \star *}$ \\
\hline Net Income & -185 & -104 & $-81^{* \star *}$ & -22 & -13 & -9 & $168^{* * *}$ & $81^{* \star *}$ & $87^{\star * *}$ \\
\hline Book/Market & -0.76 & 0.07 & $-0.83^{* *}$ & 0.66 & 0.39 & 0.27 & $1.38^{* * *}$ & 0.25 & $1.12^{* *}$ \\
\hline $\mathrm{CA} / \mathrm{TA}$ & -0.24 & -0.16 & -0.07 & 0.10 & 0.11 & -0.01 & $0.34^{* * *}$ & $0.27^{* * *}$ & 0.07 \\
\hline ROE & -0.07 & -0.01 & -0.06 & -0.17 & 0.19 & $-0.36^{\star *}$ & -0.09 & 0.17 & -0.26 \\
\hline ROA & -0.22 & -0.30 & $0.07^{*}$ & -0.04 & -0.11 & $0.07^{* *}$ & $0.19^{* * *}$ & $0.18^{* * *}$ & 0.00 \\
\hline Rev/TA & 1.05 & 1.28 & $-0.23^{* *}$ & 1.22 & 1.39 & -0.17 & $0.14^{* *}$ & $0.17^{* *}$ & -0.03 \\
\hline Equity/TL & 0.02 & 0.06 & -0.04 & 0.63 & 0.72 & -0.09 & $0.62^{* * *}$ & $0.67^{* * *}$ & -0.05 \\
\hline Z-score & -1.67 & -3.70 & $2.03^{*}$ & 3.80 & 1.52 & $2.27^{\star \star}$ & $5.47^{\star * *}$ & $5.44^{\star * *}$ & 0.03 \\
\hline
\end{tabular}

High represents the high quality group which provides a detail and complete projection information in their disclosure statement. Low represents the low quality group in which their projection information is either too brief to conduct numerical analysis or not provided. $\Delta$ High and $\Delta$ Low are the changes in those performance measures when comparing their post-bankruptcy to pre-bankruptcy level. Pre-1 is one year before bankruptcy and post-1 is one year after emergence from Chapter 11 . The significance levels are indicated with asterisks. ${ }^{* * *},{ }^{* *}$, and ${ }^{*}$ indicate that the variable is significant at $1 \%, 5 \%$, and $10 \%$ level respectively.

Table 2: Descriptive Statistics.

\begin{tabular}{|c|c|c|c|}
\hline & Post-1 & Post-2 \\
\hline Total Assets & -205 & $-305^{*}$ \\
\hline Total Liabilities & -160 & -222 \\
\hline Total Equities & $-131^{* *}$ & $-145^{* *}$ \\
\hline Net Income & $-62^{* * *}$ & $-105^{* * *}$ \\
\hline CA/TA & $-0.04^{* *}$ & $-0.05^{\star *}$ \\
\hline ROE & -0.16 & -190 \\
\hline ROA & $-0.07^{* * *}$ & $-0.29^{* * *}$ \\
\hline Rev/TA & $-0.20^{* * *}$ & $-0.11^{* * *}$ \\
\hline Equity/TL & -0.02 & $-0.19^{* * *}$ \\
\hline Z-score & $-1.41^{* * *}$ & -0.11 \\
\hline
\end{tabular}

For each performance measure, we take the post-bankruptcy level minus their projected level in the disclosure statement. Post- 1 , post-2, and post-3 are one year, two years, and three years after bankruptcy respectively. ${ }^{* *},{ }^{* *}$, and ${ }^{*}$ indicate that the variable is significant at $1 \%, 5 \%$, and $10 \%$ level respectively.

Table 3: Deviations between Post-Bankruptcy Performances and Their Projected Level. 


\begin{tabular}{|c|c|c|c|c|c|c|c|}
\hline & Total Assets & $B / M$ & CA/TA & ROE & ROA & Rev/TA & Equity/TL \\
\hline \multirow[t]{2}{*}{ Total Assets } & 1.00 & 0.08 & 0.07 & -0.02 & 0.22 & -0.25 & -0.04 \\
\hline & & $(0.29)$ & $(0.38)$ & $(0.78)$ & $(0.00)$ & $(0.00)$ & $(0.60)$ \\
\hline \multirow[t]{2}{*}{$\mathrm{B} / \mathrm{M}$} & 0.08 & 1.00 & 0.35 & -0.42 & 0.35 & -0.04 & 0.42 \\
\hline & $(0.29)$ & & $(0.00)$ & $(0.00)$ & $(0.00)$ & $(0.64)$ & $(0.00)$ \\
\hline \multirow[t]{2}{*}{ CA/TA } & 0.07 & 0.35 & 1.00 & -0.27 & 0.25 & 0.06 & 0.48 \\
\hline & $(0.38)$ & $(0.00)$ & & $(0.00)$ & $(0.00)$ & $(0.41)$ & $(0.00)$ \\
\hline \multirow[t]{2}{*}{ ROE } & -0.02 & -0.42 & -0.27 & 1.00 & -0.18 & 0.05 & -0.33 \\
\hline & $(0.78)$ & $(0.00)$ & $(0.00)$ & & $(0.02)$ & $(0.49)$ & $(0.00)$ \\
\hline \multirow[t]{2}{*}{ ROA } & 0.22 & 0.35 & 0.25 & -0.18 & 1.00 & 0.00 & 0.20 \\
\hline & $(0.00)$ & $(0.00)$ & $(0.00)$ & $(0.02)$ & & $(0.95)$ & $(0.01)$ \\
\hline \multirow[t]{2}{*}{ Rev/TA } & -0.25 & -0.04 & 0.06 & 0.05 & 0.00 & 1.00 & -0.11 \\
\hline & $(0.00)$ & $(0.64)$ & $(0.41)$ & $(0.49)$ & $(0.95)$ & & $(0.16)$ \\
\hline \multirow[t]{2}{*}{ Equity/TL } & -0.04 & 0.42 & 0.48 & -0.33 & 0.20 & -0.11 & 1.00 \\
\hline & $(0.60)$ & $(0.00)$ & $(0.00)$ & $(0.00)$ & $(0.01)$ & $(0.16)$ & \\
\hline
\end{tabular}

Table 4: Correlations between All Accounting Measures in One year before Bankruptcy.

The troubled firms are more likely to emerge as an independent company out of Chapter 11. It will be interesting to test whether a more friendly court will boost up the companies' incentive to file a high quality projection.

Dummy $_{i, \text { proi }}=\alpha+\beta_{1} \mathrm{TA}_{\mathrm{i}, \mathrm{prel}}+\beta_{2} \mathrm{~B} / \mathrm{M}_{\mathrm{i}, \mathrm{prel}}+\beta_{3} \mathrm{CA} / \mathrm{TA} \mathrm{i}_{\mathrm{i}, \mathrm{rel}}+\beta_{4} \mathrm{ROE}_{\mathrm{i}, \mathrm{prel}}+\beta_{5} \mathrm{R}$ $\mathrm{OA}_{\mathrm{i}, \mathrm{prel}}+\beta_{6} \mathrm{Rev} / \mathrm{TA} \mathrm{i}_{\mathrm{i} \text { prel }}+\beta_{7} \mathrm{Equity}^{\mathrm{i}} / \mathrm{TL}_{\mathrm{i}, \mathrm{prel}}+\beta_{8} \mathrm{Z}_{\mathrm{i}, \mathrm{prel}}+\beta_{9}$ Dummy ${ }_{\mathrm{i}, \text { court }}+\beta_{10} \mathrm{Du}$ $\mathrm{mmy}_{\mathrm{i}, \text { nnsmr }}+\beta_{11}$ Dummy $_{\mathrm{i} \text {,manuf }}+\beta_{12}$ Dummy $_{\mathrm{i} \text {,hitec }}+\beta_{13}$ Dummy $_{\mathrm{i}, \text { hlth }}+\beta_{14}$ Dumm $\mathrm{y}_{\mathrm{i}, \text { other }}+\varepsilon_{\mathrm{i}}$

The results in Table 5 reveal that the firms in larger sizes, low book-to-market, high liquidity, high profitability and low distress risk are the ones that tend to file a high quality projection. In short, companies in better financial conditions are more likely to file complete projection information in the disclosure statement. The regression results support our first hypothesis. Why do companies differ in their behaviors to provide the projection information? It is possible that stronger companies may have more resources, for example, to hire a group of restructuring professional to work on the plans, compared to the weaker firms that are deep under the water with shortage on cash and limited financing options (Table 5).

To address our second question, we run the following OLS regression. The dependent variable is the change in the $\mathrm{Z}$-score, as it represents the overall distress risk in a company in one year after bankruptcy compared to their pre-bankruptcy level. For the independent variables, in additional to all the inputs in previous logit regression, we further introduce two new dummies, DIP dummy, 1 for obtaining a DIP financing during Chapter 11 and 0 otherwise, and duration dummy, 1 for long duration and 0 for short duration. Obtaining appropriate financing sources could be crucial to the successfulness of a restructuring process, hence, it will be important to check out whether DIP financing is significant in improving the overall distress level in a company. We calculate the average duration, in terms of days in Chapter 11, and categorize our sample based on the median. The median duration is 315 days, therefore, if a company's duration is equal to or longer than 315 days, then we put them into long duration group and the dummy is one. Otherwise, it belongs to short duration group and the dummy is zero.

$\Delta \mathrm{Z}_{\mathrm{i}}=\alpha+\beta_{1}$ Dummy $_{\mathrm{i}, \text { proj }}+\beta_{2}$ Dummy $_{\mathrm{i}, \mathrm{DIP}}+\beta_{3}$ Dummy $_{\mathrm{i}, \text { court }}+\beta_{4}$ Dummy $_{\mathrm{i}, \mathrm{d}}$ uration $+\beta_{5} \mathrm{TA}_{\mathrm{i} \text {,prel }}+\beta_{6} \mathrm{~B} / \mathrm{M}_{\mathrm{i} \text {,prel }}+\beta_{7} \mathrm{CA} / \mathrm{TA}_{\mathrm{i}, \mathrm{prel}}+\beta_{8} \mathrm{ROE}_{\mathrm{i} \text {,prel }}+\beta 9 \mathrm{ROA} \mathrm{i}_{\mathrm{i} \text {,pre }}+\beta_{10} \mathrm{R}$

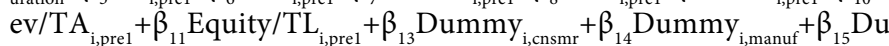
$\mathrm{mmy}_{\mathrm{i}, \text { hitec }}+\beta_{16}$ Dummy $_{\mathrm{i}, \text { hlth }}+\beta_{17}$ Dummy $_{\mathrm{i} \text {,ther }}+\varepsilon_{\mathrm{i}}$
The regression results are shown in Table 6. Unfortunately, our projection dummy is not a significant explanatory factor. In other words, we do not find sufficient evidence to support our second hypothesis that firms providing high quality projection information tend to enjoy a more significant improvement out of Chapter 11 bankruptcy compared to low quality group. On the other hand, the most contributing factors are the liquidity and profitability. Firms with high liquidity and high profitability can enjoy more significant improvements throughout the restructuring process.

Last but not the least, we also test what factors contributes the most to the deviation between actual performances and their projected level. A greater deviation indicates a more significant improvement and better post-bankruptcy performance. We run the following regression for up to three years after bankruptcy.

$\Delta Z_{\text {i,post-projt }}=\alpha+\beta_{2}$ Dummy $_{\text {i,DIP }}+\beta_{3}$ Dummy $_{\mathrm{i}, \text { court }}+\beta_{4}$ Dummy $_{\text {i,duration }}+$ $\beta_{5} \mathrm{TA}_{\mathrm{i}, \text { prel }}+\beta_{6} \mathrm{~B} / \mathrm{M}_{\mathrm{i}, \text { pre1 }}+\beta_{7} \mathrm{CA} / \mathrm{TA} \mathrm{i}_{\mathrm{i} \text {,prel }}+\beta_{8} \mathrm{ROE}_{\mathrm{i} \text {, pre1 }}+\beta_{9} \mathrm{ROA}_{\mathrm{i} \text {,pre1 }}+\beta_{10} \mathrm{Rev} /$

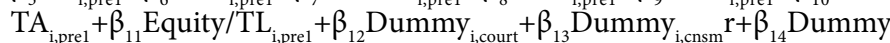
${ }_{\mathrm{i}, \text { manuf }}+\beta_{15}$ Dummy $_{\mathrm{i}, \text { hitec }}+\beta_{16}$ Dummy $_{\mathrm{i}, \text { hlth }}+\beta_{17}$ Dummy $_{\mathrm{i} \text {,other }}+\varepsilon_{\mathrm{i}}$

Our results are listed in Table 7. We do find a short-term duration effect when comparing post-1 with their corresponding projected level. The first year after bankruptcy might be the most crucial time to verify the effectiveness of the restructuring plan. Consistent with previous literature that short duration is a proxy for a more feasible and efficient turnaround process, our results confirm that short duration actually generates a larger deviation. In addition, higher profitability and lower debt burden also help the companies to enjoy better post-bankruptcy performances. Further, it is not surprising to see that, as time goes by, the explanatory power of pre-bankruptcy status decrease over the times and our regression become insignificant in explaining the deviation three years after bankruptcy. When companies emerge from Chapter 11 and continue to operate on their own, over the time there will be other elements influencing their performances.

\section{Conclusion}

There is a significant difference in the corporate behavior in terms of ways they file the projection information in disclosure statement during Chapter 11 process. In this paper, we examine the factors that lead to the difference and whether the divergence shed light on their post-bankruptcy performances. Based on a group of accounting performance measures and indicator variables, our paper is one of the first studies to identify the firms in better financial condition will be more likely to file a detail and complete projection information 
Citation: Branch B, Xu M (2014) Can Projection Information Shed Light On Post Bankruptcy Performance? Bus Eco J 5: 084. doi: 10.4172/21516219.1000084

Page 6 of 7

\begin{tabular}{|c|c|c|}
\hline & Estimates & p-value \\
\hline Intercept & -0.891 & 0.182 \\
\hline Total Assets & $0.002^{\star *}$ & 0.013 \\
\hline B/M $\mathrm{M}_{\text {pre }}$ & $-0.267^{* \star}$ & 0.010 \\
\hline CA/TA & $2.222^{* * *}$ & 0.002 \\
\hline ROE & $0.247^{*}$ & 0.096 \\
\hline ROA & -0.295 & 0.730 \\
\hline Rev/TA & -0.020 & 0.949 \\
\hline Equity/TL & 0.785 & 0.113 \\
\hline Z-score & $0.084^{\star *}$ & 0.034 \\
\hline District & 0.527 & 0.161 \\
\hline Cnsmr & -0.401 & 0.494 \\
\hline Manuf & -0.399 & 0.499 \\
\hline HiTec & 0.346 & 0.578 \\
\hline Hlth & -0.435 & 0.599 \\
\hline Other & 0.647 & 0.611 \\
\hline
\end{tabular}

Coefficients and $p$-values of the following regression: Dummy ${ }_{i, p r o i}=\alpha+\beta_{1} T A_{i, \text { pre }}+\beta_{2} B$

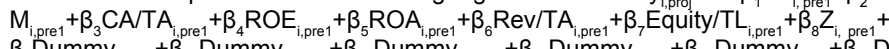

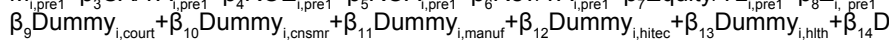
ummy $\mathrm{i}_{\mathrm{i} \text { other }}+\varepsilon_{\mathrm{i}}$.

Table 5: Logistic Regression: What Type of Companies Tend to File High Quality Projection?

\begin{tabular}{|c|c|c|}
\hline & Estimates & p-value \\
\hline Intercept & $3.630^{*}$ & 0.061 \\
\hline Projection & -0.296 & 0.797 \\
\hline DIP & 0.426 & 0.804 \\
\hline District & -1.037 & 0.328 \\
\hline Duration & 0.104 & 0.924 \\
\hline TA & 0.000 & 0.144 \\
\hline BM & -0.268 & 0.339 \\
\hline CA/TA & $3.414^{* * *}$ & 0.000 \\
\hline ROE & 0.511 & 0.187 \\
\hline ROA & $4.259^{* *}$ & 0.050 \\
\hline Rev/TA & -0.137 & 0.878 \\
\hline Equity/TL & $3.499^{* *}$ & 0.015 \\
\hline Cnsmr & 1.177 & 0.476 \\
\hline Manuf & -0.764 & 0.644 \\
\hline HiTec & 2.174 & 0.194 \\
\hline Hlth & -1.900 & 0.409 \\
\hline Other & 0.952 & 0.830 \\
\hline F-Value & 6.68 & \\
\hline R-square & $42 \%$ & \\
\hline N & 211 & \\
\hline
\end{tabular}

Coefficients and $p$-values of the following regression:


TLi,pre1 $+\beta_{13}$ Dummy $_{i, \text {,nsmr }}+\beta_{14}$ Dummy $_{i, \text { manuf }}+\beta_{15}$ Dummy $_{i, \text { hitec }}+\beta_{16}$ Dummy $_{i, \text { hlth }}+$ $\beta_{17}$ Dummy $_{i, \text { other }}+\varepsilon_{i}$

Table 6: OLS Regression: Whether High Quality Projection Indicates Better PostBankruptcy Performance.

in disclosure statement. However, by filing a high quality projection does not guarantee a successful turnaround for those bankrupt firms. Instead, liquidity and profitability are always the key contributors that the distress firms should focus on. For further research, it will be interesting to test whether the different corporate behavior could be extended into their stock performances. For example, we can take the risk-adjusted measure, Sharpe Ratios, as dependent variable and test whether projection can offer some power in explaining the returns. In addition, we can incorporate some alternative measures to evaluate the projection quality, such as the numbers of accounting ratios provided,

\begin{tabular}{|c|c|c|c|}
\hline & Post-1 & Post2 & Post3 \\
\hline \multirow[t]{2}{*}{ Intercept } & 1.037 & 2.198 & -0.467 \\
\hline & 0.558 & 0.268 & 0.859 \\
\hline \multirow[t]{2}{*}{ DIP } & 1.482 & -0.573 & 0.156 \\
\hline & 0.296 & 0.715 & 0.944 \\
\hline \multirow[t]{2}{*}{ District } & -0.411 & 0.517 & -0.003 \\
\hline & 0.713 & 0.654 & 0.999 \\
\hline \multirow[t]{2}{*}{ Duration } & $-2.080^{*}$ & -1.612 & -2.882 \\
\hline & 0.075 & 0.159 & 0.101 \\
\hline \multirow[t]{2}{*}{$\mathrm{TA}_{\text {pre1 }}$} & 0.000 & 0.000 & 0.000 \\
\hline & 0.199 & 0.304 & 0.455 \\
\hline \multirow[t]{2}{*}{$\mathrm{BM}_{\text {pre1 }}$} & 0.238 & 0.161 & -0.019 \\
\hline & 0.400 & 0.599 & 0.974 \\
\hline \multirow{2}{*}{$\mathrm{CA} / \mathrm{TA}_{\text {pre1 }}$} & 1.271 & 0.681 & 1.361 \\
\hline & 0.454 & 0.701 & 0.626 \\
\hline \multirow[t]{2}{*}{$\mathrm{ROE}_{\text {pre1 }}$} & $0.987^{\star *}$ & $0.761^{*}$ & 1.059 \\
\hline & 0.024 & 0.092 & 0.150 \\
\hline \multirow[t]{2}{*}{$\mathrm{ROA}_{\text {pre1 }}$} & 4.272 & 0.705 & 2.001 \\
\hline & 0.119 & 0.806 & 0.644 \\
\hline \multirow[t]{2}{*}{$\mathrm{Rev} / \mathrm{TA}_{\text {pre1 }}$} & 0.093 & -1.458 & -0.928 \\
\hline & 0.921 & 0.160 & 0.528 \\
\hline \multirow{2}{*}{ Equity/TL ${ }_{\text {pre1 }}$} & 1.592 & $2.511^{*}$ & 2.953 \\
\hline & 0.281 & 0.071 & 0.610 \\
\hline \multirow[t]{2}{*}{ Cnsmr } & -0.303 & -1.633 & -0.257 \\
\hline & 0.877 & 0.400 & 0.926 \\
\hline \multirow[t]{2}{*}{ Manuf } & -2.512 & -1.937 & 1.094 \\
\hline & 0.150 & 0.264 & 0.642 \\
\hline \multirow[t]{2}{*}{ HiTec } & -0.657 & $-5.387^{* * *}$ & -2.291 \\
\hline & 0.700 & 0.005 & 0.384 \\
\hline \multirow[t]{2}{*}{ HIth } & 0.984 & -0.213 & 4.684 \\
\hline & 0.706 & 0.936 & 0.264 \\
\hline \multirow[t]{2}{*}{ Other } & -0.302 & 0.677 & -1.448 \\
\hline & 0.880 & 0.990 & 0.863 \\
\hline F-Value & $1.59^{*}$ & $2.05^{\star *}$ & 0.91 \\
\hline R-square & $27.0 \%$ & $41.2 \%$ & $33.8 \%$ \\
\hline $\mathrm{N}$ & 211 & 211 & 211 \\
\hline
\end{tabular}

Coefficients and $p$-values of the following regression:

$\Delta Z_{i, \text { post-projt }}=\alpha+\beta_{2}$ Dummy $_{i, \text { DIP }}+\beta_{3}$ Dummy $_{i, \text { court }}+\beta_{4}$ Dummy $_{\text {i,duration }}+\beta_{5} \mathrm{TA}_{\text {i,pre } 1}+\beta_{6} \mathrm{~B} /$

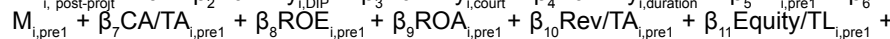
$\beta_{12}$ Dummy $_{i, \text { court }}+\beta_{13}$ Dummy $_{i, \text { cnsmr }}+\beta_{14}$ Dummy $_{i, \text { manuf }}+\beta_{15}$ Dummy $_{i, \text { hitec }}+\beta_{16}$ Dummy $_{i, \text { hth }}$ $+\beta_{17}$ Dummy $_{i, \text { other }}+\varepsilon$

Table 7: OLS Regression: Factors Explaining the Deviations When Comparing Post-Bankruptcy vs. Projection

and instead of the binary status of either zero or one, we can assign a ranking to further categorize the projection quality.

\section{References}

1. Hotchkiss E (1995) Post-Bankruptcy Performance and Management Turnover. Journal of Finance 1: 3-21.

2. Eberhart A, Edward A, Aggarwal R (1999) The Equity Performance of Firms Emerging from Bankruptcy. Journal of Finance 54: 1855-1868.

3. Bris A, Welch I, Zhu N (2006) The Costs of Bankruptcy: Chapter 7 Liquidation Versus Chapter 11 Reorganization. Journal of Finance 3: 1253-1303.

4. Hotchkiss E, Mooradian R (1998) Acquisitions as a Means of Restructuring Firms in Chapter 11. Journal of Financial Intermediation 7: 240-262.

5. Morrison E (2007) Bankruptcy Decision Making: An Empirical Study of Continuation Bias in Small Business Bankruptcies. Journal of Law and Economics 50: 381-419.

6. Hotchkiss E (1993) Investment Decisions under Chapter 11 Bankruptcy Doctoral dissertation, New York University, USA.

7. Denis D, Rodgers K (2007) Chapter 11: Duration, Outcome, and Post- 
Citation: Branch B, Xu M (2014) Can Projection Information Shed Light On Post Bankruptcy Performance? Bus Eco J 5: 084. doi: 10.4172/21516219.1000084

Page 7 of 7

Reorganization Performance. Journal of Financial and Quantitative Analysis 42: 101-118

8. Li K (1999) Bayesian Analysis of Duration Models: An Application to Chapter 11 Bankruptcy. Economics Letters 63: 305-312.

9. Lehavy R (2002) Reporting Discretion and the Choice of Fresh Start Values in Companies Emerging from Chapter 11 Bankruptcy. Review of Accounting Studies: $53-73$
10. Gilson S, Hotchkiss E, Ruback R (2000) Valuation of Bankrupt Firms. Review of Financial Studies 13: 43-74.

11. Betker B, Ferris S, Lawless R (1999) Warm with Sunny Skies: Disclosure Statement Forecasts. American Bankruptcy Law Journal 73: 809-837.

12. Altman E, Hotchkiss E (2006) Corporate Financial Distress and Bankruptcy: Third Edition. Wiley Finance, USA. 